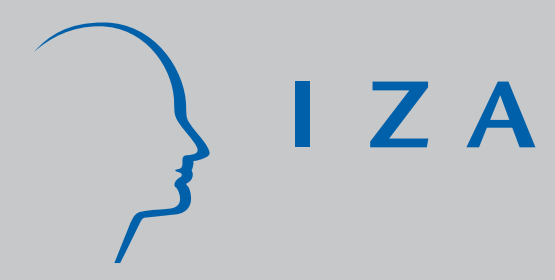

IZA DP No. 3054

The Value Relevance of Top Executive Departures:

Evidence from the Netherlands

Kees Cools

C. Mirjam van Praag

September 2007 


\title{
The Value Relevance of Top Executive Departures: Evidence from the Netherlands
}

\author{
Kees Cools \\ University of Groningen \\ and Boston Consulting Group \\ C. Mirjam van Praag \\ University of Amsterdam, Tinbergen Institute, \\ Max Planck Institute of Economics Jena and IZA
}

Discussion Paper No. 3054

September 2007

\author{
IZA \\ P.O. Box 7240 \\ 53072 Bonn \\ Germany \\ Phone: +49-228-3894-0 \\ Fax: +49-228-3894-180 \\ E-mail: iza@iza.org
}

\begin{abstract}
Any opinions expressed here are those of the author(s) and not those of the institute. Research disseminated by IZA may include views on policy, but the institute itself takes no institutional policy positions.

The Institute for the Study of Labor (IZA) in Bonn is a local and virtual international research center and a place of communication between science, politics and business. IZA is an independent nonprofit company supported by Deutsche Post World Net. The center is associated with the University of Bonn and offers a stimulating research environment through its research networks, research support, and visitors and doctoral programs. IZA engages in (i) original and internationally competitive research in all fields of labor economics, (ii) development of policy concepts, and (iii) dissemination of research results and concepts to the interested public.
\end{abstract}

IZA Discussion Papers often represent preliminary work and are circulated to encourage discussion. Citation of such a paper should account for its provisional character. A revised version may be available directly from the author. 
IZA Discussion Paper No. 3054

September 2007

\section{ABSTRACT \\ The Value Relevance of Top Executive Departures: Evidence from the Netherlands}

On theoretical grounds, monitoring of top executives by the (supervisory) board is expected to be value relevant. The empirical evidence is ambiguous and we analyze three noncompeting explanations for this ambiguity: (i) The positive effect on firm value of board monitoring is hidden in stock price effects due to the simultaneous occurrence of the positive real effect of monitoring and the opposing information effect. (ii) The combination of board monitoring and monitoring by other parties prevents assessing the value relevance of board monitoring in isolation. (iii) The confounding effect of a simultaneous successor appointment typically generates an upward biased estimate. Based on an analysis of price effects and trading volumes at announcement, we conclude that monitoring by the supervisory board is valued by investors: Forced departures of executive directors, also without a successor appointment, are value relevant in the Netherlands where external control mechanisms and shareholder control were virtually absent in the period studied (1991-2000).

JEL Classification: J32, J33, M12, M51, G3

Keywords: $\quad$ top management departure, dismissal, corporate governance, internal monitoring, value relevance

Corresponding author:

C. Mirjam van Praag

University of Amsterdam

Roetersstraat 11

1018 WB Amsterdam

The Netherlands

E-mail: c.m.vanpraag@uva.nl

\footnotetext{
* We thank Paul Huigens and Jelger Mol for their research assistance. We greatly appreciate the comments by Arnoud Boot, Luc Renneboog, and an anonymous referee and editor on earlier versions of the paper. Moreover, we thank seminar participants at Warwick University, Erasmus University Rotterdam, Univerity of Tilburg, and conference participants at the EALE in Sevilla and at the EFA in Maastricht.
} 


\section{Introduction}

This paper reconsiders the value relevance of the monitoring of top executives by (supervisory) boards. If monitoring were serving shareholders' interests, the market would value unanticipated forced management departures resulting in positive abnormal returns subsequent to the announcement of an executive's dismissal. However, previous (event) studies have collectively found little evidence supporting the value relevance of unanticipated forced management departures. The theoretical value relevance of board monitoring in contrast to the inconclusive empirical results remains puzzling. We try to contribute to understanding this puzzle by testing three possible non-competing explanations.

Warner et al. (1988) provide the first possible explanation: The measured effect of unanticipated forced management departures on stock returns at announcement is ambiguous since it is the sum of two opposing effects. One is a real monitoring effect that is positive if the unanticipated change of management is in the shareholders' interests. The second is an information effect that is negative if the change signals worse (management) performance than anticipated.

In models that study the effects of differences of opinion amongst investors, trading volume typically proxies for the intensity of disagreement. Therefore, in addition to the effect on stock prices, we analyze the effects on trading volumes of the announcement of an executive's dismissal to test Warner's explanation of the puzzling inconclusive empirical results. It is a novel application in studies of (forced) management turnover effects.

Secondly, we address the explanation for the variety of empirical results by Denis and Denis (1995). They state that forced departures measured to date are more often due to external factors than to normal board monitoring. Therefore, it is not clear whether board monitoring would function effectively in isolation. We primarily address this issue by analyzing the effect of forced departures in a country where the external control market was minimal in the period studied (1991-2000) and shareholders had virtually no control rights, i.e. the Netherlands.

A third factor that we analyze is the additional effect of successor announcements. It is quite common, especially for CEO's, that departures are announced simultaneously with a successor appointment. Furtado and Rozeff (1987) therefore conclude that the evidence for dismissals is overestimated, since the appointment of a successor tends to generate a positive price effect (Dedman and Lin, 2002). We distinguish between unanticipated announcements of forced departures that simultaneously mention the appointment of a successor and pure announcements of forced departures.

In addition to these three explanations, a measurement problem might contribute to the lack of consistent empirical results (Denis and Denis, 1995): the definition of forced executive departures. The imprecise definitions often used lead to underestimating the effect of forced departures on stock prices. We try to address this problem by using inputs about exit motives from the popular business press, financial analysts and boardroom consultants, along with the usual press releases. 
Based on our analyses of stock prices and trading volumes we conclude that forced executive departures are value relevant in the Dutch case: Monitoring by the supervisory board generates a positive (real) value effect that is normally concealed from price effects by the negative information effect, although price effects are often overstated by the positive confounding effects of external monitoring and successor announcements.

The remainder of the paper is divided into six sections. The next section positions our study in the empirical literature. Section 3 discusses how we isolate the effect of monitoring by the (supervisory) board. Section 4 details on our approach of analyzing trading volume effects. Section five discusses the data and the applied methodology of event studies. In section 6 we discuss the empirical results. Section 7 concludes.

\section{Review of the literature}

We distinguish three categories of studies that analyze the relationship between firm performance and executive departures.

One group of studies investigates whether management departure is preceded by declines in operating or stock performance. If monitoring were effective, a greater incidence of top management departures would be observed in poorly performing firms. The empirical evidence in this category is consistent with effective monitoring and control. ${ }^{2}$

The second category of studies examines the effect of executive departures on long-term firm performance (e.g. Murphy and Zimmerman, 1993 and Denis and Denis, 1995). The evidence is mixed. ${ }^{3}$

\footnotetext{
${ }^{2}$ Coughlan and Schmidt (1985), Warner et al. (1988), Weisbach (1988), Jensen and Murphy (1990), Kaplan (1994a,b), Denis and Denis (1995), Fee and Hadlock (2000, 2004), Renneboog (2000), Franks and Mayer (2001), Franks et al. (2001), Dahya et al. (2002), Lausten (2002), Volpin (2002), Jenter and Kanaan (2006) and Kaplan and Minton (2006) indeed find that the rate of top executive departures is inversely related to prior performance for various countries. Danisevska et al. (2004) document this for the Dutch case.

${ }^{3}$ Several studies, like Köke (2004), have found insignificant effects, supporting the hypothesis that managers have little influence on long-term firm performance. For the Netherlands, Olie et al. (2004) have found that executive exits do not affect long term accounting performance, whereas simultaneous exits and entries of CEO's have a positive relationship with long term firm performance. Other studies support the hypothesis that unanticipated management turnover would affect long-term firm performance negatively, due to a period of tension and insecurity resulting from the change (Allen et. al, 1979). Early applications pertain to sporting team performance after coaches' resignations in particular (for instance, Brown, 1982; and Boeker, 1992).
} 
The third category examines stock market reactions associated with the announcement of (forced) management departures by means of event study methodology. This study falls within that category, though existing studies focus on stock price effects only. The evidence from this category of studies is mixed. Table 1 shows an overview of empirical results obtained in studies of the stock price effects subsequent to the announcement of forced executive departures in various countries, periods of time and event windows. 
Table 1

Overview of empirical findings in studies that explicitly distinguish forced turnover

\begin{tabular}{|c|c|c|c|c|c|c|c|c|c|c|c|}
\hline Study & \begin{tabular}{|l} 
I \\
1987
\end{tabular} & \begin{tabular}{|l|} 
II \\
1988
\end{tabular} & \begin{tabular}{|l} 
III \\
1988
\end{tabular} & \begin{tabular}{|l|} 
IV \\
1993 \\
\end{tabular} & \begin{tabular}{|l|}
$V$ \\
1995
\end{tabular} & \begin{tabular}{|l|} 
VI \\
1996 \\
\end{tabular} & $\begin{array}{l}\text { VII } \\
2001\end{array}$ & \begin{tabular}{|l|} 
VIII \\
2002
\end{tabular} & \begin{tabular}{|l} 
IX \\
2002
\end{tabular} & \begin{tabular}{|l}
$X$ \\
2004
\end{tabular} & $\begin{array}{l}\mathrm{XI} \\
2006\end{array}$ \\
\hline Country studied & US & US & US & US & US & Japan & US & UK & France & Netherlands & US \\
\hline Period studied & 1975-1982 & 1974-1983 & 1962-1978 & 1972-1983 & 1985-1988 & $1985-1990$ & 1971-1994 & 1990-1995 & 1988-1992 & 1993-1999 & 1993-2001 \\
\hline Exec function $^{1}$ & TOP & CEO & TOP & TOP & TOP & CEO & CEO & CEO & CEO & CEO & $\mathrm{CEO}$ \\
\hline $\begin{array}{l}\text { Price effect \% } \\
\text {-total sample- }\end{array}$ & n.a. & $0.35^{*}$ & 0.31 & 0.24 & $0.63 * *$ & $0.52 * *$ & $0.50 * *$ & $-0.76^{* *}$ & n.a. & insign & n.a. \\
\hline \# departures $(\mathrm{N})$ & n.a. & 259 & 279 & 218 & 328 & 416 & 854 & 138 & n.a. & 80 & n.a. \\
\hline $\begin{array}{l}\text { Price effect \% } \\
\text {-forced dept.- }\end{array}$ & $1.03 * *$ & $0.54 * *$ & 0.14 & $-0.73 * *$ & $2.50 * *$ & $1.02 * *$ & $2.49 * *$ & $-3.98 * *$ & 0.004 & -0.54 & $-1.83 * *$ \\
\hline $\begin{array}{l}\text { \# forced } \\
\text { departures }(\mathrm{N})\end{array}$ & 63 & 153 & 56 & 39 & 69 & 81 & 127 & 24 & 37 & 32 & 336 \\
\hline $\begin{array}{l}\text { Definition forced } \\
\text { departures }\end{array}$ & Dismissals & $\begin{array}{l}\text { Younger } \\
\text { than } 64\end{array}$ & $\mathrm{See}^{2}$ & $\begin{array}{l}\text { Fired/ } \\
\text { Involuntary } \\
\text { loss of power }\end{array}$ & $\mathrm{See}^{3}$ & $\begin{array}{l}\text { Not remain } \\
\text { in Board }\end{array}$ & $\mathrm{See}^{4}$ & $\begin{array}{l}\text { Press } \\
\text { suggested } \\
\text { forced }\end{array}$ & $\begin{array}{l}\text { No renewal } \\
\text { of contract } \\
\text { or conflict }\end{array}$ & $\mathrm{See}^{5}$ & $\mathrm{See}^{\mathrm{II}}$ \\
\hline Event window & {$[-20,3]$} & {$[-1,1]$} & {$[-1,0]$} & {$[-1,0]$} & {$[-1,0]$} & {$[-1,0]$} & {$[-1,0]$} & {$[0]$} & {$[-1,0]$} & {$[-1,1]$} & {$[-1,3]$} \\
\hline
\end{tabular}

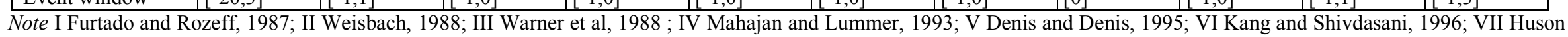

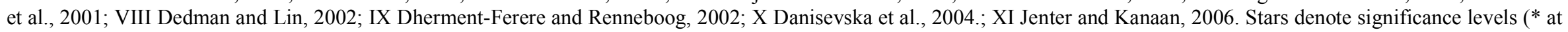
the 90 percent level; $* *$ at the 95 percent level.

${ }^{1}$ Studies pertain either to CEO's only ("CEO"), or to all top executives, i.e. the President, Vice-president, CEO, and Chairman of the Board ("TOP”).

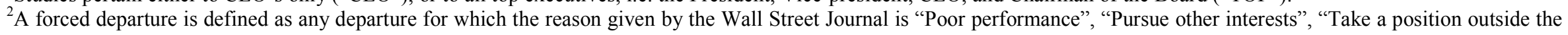
firm", "Policy interests", "Fired" or "No reason".

${ }^{3}$ If WSJ reason is "Forced", "Conflict" or "Poor performance" or if the departing manager is younger than 64 and he has an external successor.

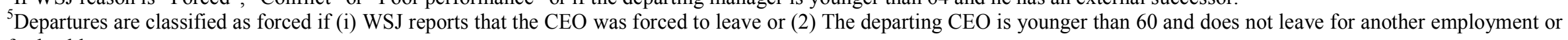
for health reasons.

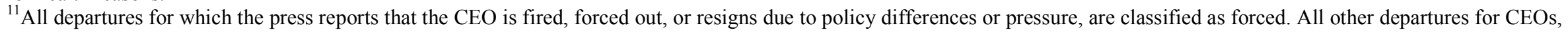

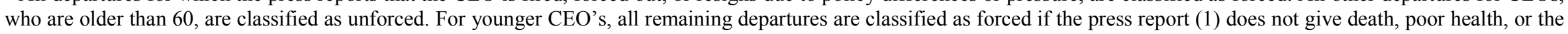

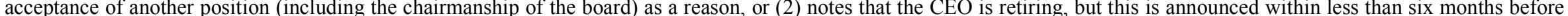

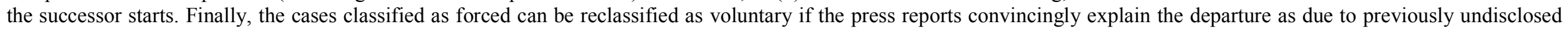
personal or business reasons that are unrelated to the firm's activities. 
Furtado and Rozeff (1987), Denis and Denis (1995), Weisbach (1988), Huson et al. (2001) and Kang and Shivdasani (1996) document a significantly positive price reaction to the announcement of a forced executive departure, whereas the other studies included in Table 1 do not support the value relevance of monitoring of top management. ${ }^{4}$

Based on the literature, we put forth three explanations to better understand the variety of empirical results that is at odds with effective board monitoring of executives:

\subsection{Board monitoring versus other control mechanism}

The monitoring activity by shareholders and members of the supervisory board (or non-executive directors in a one tier system of corporate governance) is generally considered as "internal" monitoring, whereas monitoring activities by acquiring shareholders are considered "external", cf. Brickley et al., 2003. A basic distinction across national corporate governance systems is between "insider" and “outsider" systems (Franks and Mayer, 2001). In "outsider" systems, prevalent in Anglo-Saxon countries, executive performance is maintained by the complementary intervention of both internal and external control mechanisms and shareholders are relatively well protected by the legal system. ${ }^{5}$ "Insider" systems, prevalent in Continental Europe, mainly rely on internal monitoring (cf. Shleifer and Vishny, 1997). A small number of listed firms, concentrated share ownership, and relatively low levels of takeover activities are their main characteristics (Franks and Mayer, 2001).

Denis and Denis (1995) state that there is surprisingly little evidence on the value relevance of board control in generating improvements in corporate performance. Examination of their dataset reveals that $68 \%$ of the dismissals are preceded by active monitoring by parties other than the supervisory board, e.g. creditors, shareholders, or potential acquirers. Hence, little support has been found for the hypothesis that supervisory boards would function effectively in isolation.

\subsection{Simultaneous occurrence of real monitoring effect and information effect}

Warner et al. (1988) explain the insignificant price effects subsequent to the announcement of forced management turnover by the simultaneous occurrence of a positive real monitoring effect and a negative information effect. They demonstrate empirically that this is the case by a combination of insignificant average abnormal price effects and significant shifts in variances, indicating that stock price effects exist, regardless of their sign. However, the analysis of shifts in variances does not detect all potential value relevant events. If events do not evoke a significant stock price effect, whether negative or positive, which will turn out to be the majority, variances will not shift either. However, such events might still conceal a combination of a real and information effects and therefore be value relevant.

\footnotetext{
${ }^{4}$ Mahajan and Lummer (1993), Danivevska et al. (2002) and Jenter and Kanaan (2006) even report a statistically significant negative stock price reaction to forced CEO turnover.

5 Shareholders typically have the legal right to vote on important corporate matters, such as mergers and liquidations, as well as electing and discharging the board of directors (cf. Shleifer and Vishny, 1997)
} 
Kang and Shivdasani (1996) observe a negative relationship between prior industry-adjusted stock returns and abnormal stock returns subsequent to the announcement of a management departure. This finding is consistent with the view that turnover announcements reveal adverse information about management performance. They conclude that the observed stock-price reaction is likely to be a conservative estimate of the improvement in underlying firm value caused by the dismissal of inefficient management.

\subsection{Effect of successor announcement}

It is quite common, especially for CEO's, that departures are announced simultaneously with new appointments. Furtado and Rozeff (1987) therefore conclude that the evidence for pure dismissals is highly tentative. They find that the announcement of appointments tends to generate a positive effect. Dedman and Lin (2002) are the only ones to provide evidence that the sub-set consisting of pure dismissal announcements generate lower abnormal returns than combined announcements of dismissals and successors.

\subsection{Definition of forced departures}

A complicating factor in measuring announcement effects of forced departures is that bad performance and the like is seldom mentioned in press releases as a reason for executive departure. Table 1 shows the variety of classification mechanisms that have been used to identify forced departures in event studies.

Denis and Denis (1995) have documented that various classification mechanisms lead to different measured stock price effects of forced departures. They report a positive effect for their own definition, but an insignificant effect when adopting the definition used by Warner et al. A frequently used classification system, to label all external appointments as forced, leads to insignificant results too. They conclude that their classification scheme (see Table 1) identifies forced resignations more precisely than prior studies and, more in general, that classification schemes are relevant since they affect the outcome of the analysis.

In what follows, we discuss our approach to assessing the validity of these three explanations for the ambiguity of the results from previous studies. We shall also discuss how we deal with the fourth issue, the measurement of forced departures. In the next section, we consider the possibilities for isolating the effect of supervisory board monitoring.

\section{$3 \quad$ Isolating the effect of monitoring by the supervisory board}

We follow a two-step approach. As a first step, we select the Netherlands in the 1990's as the country and period of analysis. At the time, the Netherlands had a very insider oriented corporate governance system in which shareholders exerted relatively little influence, whereas the supervisory board was very influential. Hence, the value effects that we find can largely be attributed to monitoring by the supervisory board. Second, we will analyze the effect of governance-related characteristics that vary 
across firms and potentially influence the relative role of board control and therefore the value effects of forced departures. ${ }^{6}$

\subsection{Legal structure}

The focal point of the Dutch regime of corporate governance is the two-tier board structure consisting of a management board in charge of the firm's operations and a separate supervisory board exclusively consisting of non-executive directors. In performing their duties, the supervisory board members are required by Dutch company law to act as a delegated monitor of all stakeholders (De Jong et al., 2004).

The scope of influence of the supervisory board depends on the legal regime the firm adopts. There are three such forms. The first form is the so-called "structuur regime" that companies are forced to adopt if they: (1) are a limited liability company, (2) have a subscribed capital exceeding US \$12 million, (3) employ more than 100 employees within the Netherlands and have a legally installed work council (Van Ees et al., 2003). ${ }^{7}$ Under the "structuur regime", the installation of a supervisory board is mandatory and members are selected by co-optation. Many tasks and responsibilities allocated to shareholders in Anglo-Saxon countries reside under the Dutch "structuur regime" with the supervisory board, in particular the appointment and firing of the members of the management board including the CEO.

The second legal regime, the "weaker form" of the structuur regime, can be used on a voluntary basis by Dutch multinational companies that meet the criteria for the "structuur regime", but have more than $50 \%$ of their employees working outside the Netherlands. Under this regime, the management board is appointed by the annual meeting of shareholders. The supervisory board still retains most of the legal power and shareholders have a limited say (De Jong et al., 2005).

Companies not meeting the above criteria may adopt the third legal option, i.e. the common legal regime, where a supervisory board is optional, but commonplace (Van Oijen, 2000). ${ }^{8}$ Both the supervisory and management board members are appointed at the annual shareholders meeting.

Approximately $60 \%$ of the Dutch firms listed on the Amsterdam stock exchange have adopted the "structuur regime", either mandatory or voluntarily in 1999 (Van Oijen, 2000, Honée et al., 2000). 65\% of the firms with an international character - exempted from the legal obligation to adopt the "structuur regime" - have voluntarily adopted this regime in 1999 (Honée et al., 2000).

\subsection{An "Insider" system}

\footnotetext{
${ }^{6}$ Typically, systems of corporate governance, and therefore the relative role of external control, vary not only across countries, but also across firms. With respect to internal monitoring, the concentration of shareholdings, i.e. the presence and identity of block-holders varies over firms. Moreover, firms differ in the use of anti-takeover defenses.

${ }^{7}$ After the period studied, in 2004 the 'structuur regime' was renewed, allocating more rights to shareholders.

${ }^{8}$ There were four exceptions at the Amsterdam stock exchange in 1999.
} 
The Dutch corporate governance system in the 1990's meets all conditions expressed by Franks and Mayer (2001) to qualify for an "insider system": A small number of quoted firms, concentrated share ownership, and comparatively low levels of takeover activities:

At the end of 1997, only 248 Dutch companies were listed on the Amsterdam stock exchange. The Dutch stock market is highly concentrated: Only 15 companies, including Royal Dutch, Unilever, Philips Electronics, Elsevier, and ING, represent $75 \%$ of total market capitalization (De Jong et al., 2001). Moreover, the ownership structure of Dutch listed firms is rather concentrated: The mean (median) size of the largest block-holder is $27 \%$ (18\%), and that of the largest three block-holders is $41 \%$ (35\%) (De Jong et al.). ${ }^{9}$ The Netherlands certainly also meets the third requirement to qualify for an insider system, i.e. a low level of hostile takeover activities:

"Hostile takeover bids are rare in the Netherlands, and were successful, at most, on a few occasions." (Kabir et al., 1997)

"Hostile takeovers are hardly attempted in the Netherlands so that in general the threat of a hostile takeover does not act as a disciplinary device for Dutch firms." (Van Oijen, 2000)

"Even in spite of (more) concentrated ownership, Dutch anti-investor protection (including the institutional features of the structural regime) generally precludes that management is seriously disciplined by the stock market." (Van Ees et al., 2003)

The rarity of hostile takeover bids is due to the installment of (multiple) anti-takeover defenses by most Dutch listed firms. Dutch law offers companies numerous possibilities of defense mechanisms (Kabir et al., 1997), each of these limiting the number of votes that the regular shareholder has. The "structuur regime" is viewed as one of the most important anti-takeover defenses (Kabir et al., 1997; Van Oijen, 2000; Van Ees et al., 2003; De Jong et al., 2005), since the supervisory board is granted the rights previously held by shareholders (see above). $90 \%$ of the Dutch listed firms have installed one or more additional anti-takeover measures. The most commonly used additional defense mechanisms in the Netherlands are depository receipts of shares or so-called "certificates" $(34 \%)$, protective preferred shares (59\%), and priority shares (45\%), (Kabir et al., 1997). ${ }^{10}$

All in all, these takeover barriers prevent shareholders from obtaining any or more than $50 \%$ of the voting shares. In addition, proxy fights, for board seats or any other purpose, were non-existent in the 1990 's. A market for corporate control was thus virtually absent. Hence, most effects on stock prices and/or trading volumes that are generated by (forced) management turnover can be attributed to board monitoring.

\subsection{Shareholders passivism}

Not only did Dutch shareholders have virtually no voting rights in the 1990s, their presence and participation at the annual shareholders meeting was weak too. The analysis of the minutes of 245 general shareholders' meetings in the Netherlands in the period 1998-2002 by De Jong et al. (2004)

\footnotetext{
${ }^{9}$ Numbers are based on 137 Dutch industrial companies listed on the Amsterdam stock exchange in May 1996.

${ }^{10}$ The provisions of the Euronext Amsterdam stock exchange in 1997 allow a company to have two of the three takeover defenses. (De Jong et al., 2005).
} 
reveals that only about $30 \%$ of the shareholders attend the meetings. This is low in comparison to shareholder turnout in Anglo-Saxon countries, which is about 82\% (US).

In most Dutch companies, shareholders owning more than $1 \%$ of the controlling shares have the right to submit proposals at the general meeting. The analyses by De Jong et al. show that shareholders don't use this right at all: All proposals are submitted by the management board. Moreover, shareholders reject less than one percent of these proposals.

These findings show that shareholders have hardly any influence in the Netherlands. Internal monitoring by supervisory board members is predominant in Dutch listed companies.

\section{Analysis of trading volumes}

To define the contribution of an analysis of trading volumes for the assessment of the value relevance of events that generate both a real and an opposing information effect, we first require a definition of value relevance: Information disclosed by an event is value relevant if it updates investors' beliefs about the value of the firm. This definition is consistent with earlier studies (e.g. Shevlin, 1996; Heflin and Shaw, 2000). ${ }^{11}$

The most commonly used statistic of value relevance of an event is the abnormal stock return at the unanticipated announcement of that event (e.g. Kallapur and Kwan, 2004; Espahbodi et al., 2002; Holthausen and Watts, 2001; Skinner, 1996; Amir and Lev, 1996). Most events, e.g. earnings announcements, profit warnings or share repurchases have only one effect on investors' beliefs. In such cases the analysis of stock returns is necessary and sufficient to evaluate value relevance.

However, if an event reveals ambiguous information, and, in particular, if it contains both a real and an opposing information effect on investors' beliefs, the analysis of aggregate stock price effects is necessary but might not be sufficient to determine value relevance. A relevant addition to the analysis of average stock price effects (and the variance of stock returns), would be the analysis of trading volumes, since these can reveal movements of opposite signs for individual events.

There is a strand of literature showing that trading volumes indicate the intensity of disagreement across investors. These differences-of-opinion theories go back to Beaver (1968), who pointed out that price changes reflect the average change in traders' beliefs due to the announcement, whereas trading volume reflect traders' idiosyncratic reactions. Building on that basic idea, Kim and Verrecchia (1991) developed a model showing that "Trading volume reflects the sum of differences in traders' reactions; the change in price measures only the average reaction. As a result, volume is proportional to both price changes and the degree of differential precision." Hence, in the absence of aggregate abnormal returns, abnormal trading volume reflects the existence of disagreement amongst investors. ${ }^{12}$

\footnotetext{
${ }^{11}$ Shevlin (1996) defines value relevance as usefulness or information content of (newly disclosed) data. Havlin and Shaw (2000) state that value-relevant information is information that is relevant for firm value.

12 Other studies that have shown that trading volume is an indicator of the intensity of disagreement amongst investors include Harris and Raviv (1993), Kim and Verrecchia (1994), Kandel and Pearson (1995), Chen et al. (2001) and Hong and Stein (2003).
} 
Therefore, not only the presence of positive abnormal returns but also a combination of insignificant abnormal returns and positive abnormal trading volumes indicate that the real effect on investors' beliefs is positive, given a negative information effect. Hence, an analysis of trading volumes will reveal the value relevance of forced management departures, even in the absence of aggregate abnormal returns: It indicates the positive real effect of monitoring by supervisory boards, albeit in combination with a negative information effect.

\section{Data collection, definitions and methodology}

Our firm sample consists of the 100 largest firms listed on the Amsterdam Stock Exchange (AEX) at yearend 1999 , thereby representing more than $80 \%$ of the market value of Dutch listed firms. ${ }^{13}$ The annual reports of the 100 sample firms revealed that 86 firms experienced at least one executive departure in the period January 1, 1991 until January 1, 2000. The sample of events consists of the 343 executive departures that these 86 firms experienced.

\subsection{Definitions}

(Top) Management or Executives are defined as the set of individuals being member of the management board, including the CEO, excluding the supervisory board. ${ }^{14}$ We identify executive departures by comparing the names of board members in consecutive annual reports.

The announcement date of the event, $d=0$, is defined as the trading day at which the departure is announced by the company, if the announcement, i.e. the press release, is disclosed before the closing of the stock market. Otherwise, the next trading day is labeled $d=0$. Exact announcement dates of events have been identified in Het Financieele Dagblad, the Dutch equivalent of the Wall Street Journal. To obtain the announcement date as exactly as possible, we searched in the relevant journal articles for exact descriptions of notification, such as "yesterday was announced that ...", or "a press release that appeared Monday after closure of the stock exchange" ${ }^{15}$ Exact announcement dates were identified for 256 ( 75 percent) of the 343 management changes. ${ }^{16}$

Besides $d=0$, we shall utilize three alternative event windows (EW) over short time intervals, leading to the analysis of four event windows in total:

- $\quad \mathbf{E W} \mathbf{I}[d=0]$ : Market efficiency suggests this to be the relevant event window.

- $\quad$ EW II $[d=-10, d=-1]$ : Tracing possible information leakage before the press release.

\footnotetext{
${ }^{13}$ All firms in the sample have been listed at least one year prior to yearend 1999 (to have sufficient stock market data). A number of firms merged, changed name, or was acquired or split up in the period of analysis. For these firms data were gathered for the original firms, too. Our final sample thus consists of more than 100 firms.

${ }^{14}$ Non-CEOs are forced from office at a rate that is at least as large as that for CEOs. Moreover, the sensitivity of non-CEO turnover to firm performance is lower than for CEOs (Fee and Hadlock, 2004).

${ }^{15}$ Our definition of the announcement date differs from the usual definition, which is the day the announcement is published in the newspapers. Hence, usually the exact timing of the press release is not verified (i.e. before or after the closing of the stock market). Therefore, the two day window $d=[-1,0]$ is commonly used as the main event window.

${ }^{16}$ The $75 \%$ is similar to the $70 \%$ dates of management changes identified by Denis and Denis (1995).
} 
- $\quad$ EW III $[d=-1]$ : Checking the possibility of an information leakage of one day.

- EW IV $[d=0, d=1]$ : Considering a possible additional belated announcement effect on $d=1$, especially relevant if the information is released shortly before the stock market closes.

The estimation window covers the period of 200 transaction days prior to the event window. Any kind of contaminating information announced during any event window was reason to eliminate an observation from the sample, except for the simultaneous announcement of a successor. In total 29 confounding events out of 256 were eliminated, for instance, due to confounding earnings and dividend announcements. The remaining sample consists of 227 'clean' management departures. ${ }^{17}$

One of the potential flaws in existing studies is a truthful assessment of the real reason of a management departure in case of forced departures (Denis and Denis, 1995; Jenter and Kanaan, 2006). We define departures as forced whenever Het Financieele Dagblad states a departure to be due to: (i) conflicts with other management board members, for instance on strategic or management issues, (ii) conflicts with the supervisory board causing the supervisory board to initiate the executive's departure, (iii) bad performance or inadequate management, and (iv) a scandal, i.e. externally (often press) initiated "disgraceful" events (e.g. illegitimate insider trading). This leads to a sample of 30 forced departures. Moreover, we identified departures of which the business press and/or analyst reports speculated that they were forced, though the officially published motive was either "personal" or "not published". These "rumors" were verified through a well-informed corporate network of top management consultants. The resulting number of forced management departures is 41 , including eleven "allegedly" forced departures that will be earmarked accordingly. Table 2, panel 1, documents the number of events per exit motive. The first column shows numbers, upon taking only officially published information into account, whereas the numbers in the second column are based on our described and verified search through press and analyst reports. Similar to other studies retirement is the most commonly reported reason (38\%).

${ }^{17}$ Datastream provides stock return data for all events and trading volume data for all but 22 events. 
Table 2

Sample frequencies of exit motives of departing executives (for CEO's between brackets) and the subsamples analyzed

\begin{tabular}{|c|c|c|c|c|c|}
\hline \multicolumn{6}{|c|}{ Panel 1 Exit motives, numbers and explanations } \\
\hline & Exit Motive & \multicolumn{2}{|c|}{ Explanation } & $\begin{array}{l}\text { Official } \\
\text { motive }\end{array}$ & $\begin{array}{l}\text { Official/"alleged } \\
\text { " motive }\end{array}$ \\
\hline & Sample & \multirow{2}{*}{\multicolumn{2}{|c|}{$\begin{array}{l}\text { Natural unforced anticipated contract } \\
\text { terminations }\end{array}$}} & $227(86)$ & $227(86)$ \\
\hline 1 & Pension & & & $86(47)$ & $86(47)$ \\
\hline 2 & Health-related & \multicolumn{2}{|c|}{$\begin{array}{l}\text { Executive exit due to bad health } \\
\text { conditions }\end{array}$} & $12(3)$ & $12(3)$ \\
\hline 3 & Death & \multicolumn{2}{|c|}{ Unexpected death of executive } & $3(0)$ & $3(0)$ \\
\hline 4 & Internal change of function & \multicolumn{2}{|c|}{$\begin{array}{l}\text { Executive moves to comparable } \\
\text { function in company }\end{array}$} & $12(2)$ & $12(2)$ \\
\hline 5 & External change of function & \multicolumn{2}{|c|}{$\begin{array}{l}\text { Executive changes to (comparable) } \\
\text { position in another company }\end{array}$} & $30(8)$ & $30(8)$ \\
\hline 6 & Personal & \multicolumn{2}{|c|}{ For instance family, (r)emigration } & $36(8)$ & $30(7)$ \\
\hline 7 & $\begin{array}{l}\text { Difference of opinion within } \\
\text { management. board }\end{array}$ & \multicolumn{2}{|c|}{$\begin{array}{l}\text { Difference of opinion on strategic, } \\
\text { policy or management issues }\end{array}$} & $10(0)$ & $13(1)$ \\
\hline 8 & $\begin{array}{l}\text { Difference of opinion with } \\
\text { supervisory. Board }\end{array}$ & \multicolumn{2}{|c|}{$\begin{array}{l}\text { Supervisory board initiates executive's } \\
\text { exit }\end{array}$} & $6(5)$ & $9(6)$ \\
\hline 9 & Bad performance & \multicolumn{2}{|c|}{$\begin{array}{l}\text { Executive is fired due to his bad } \\
\text { performance or management. }\end{array}$} & $11(6)$ & $16(6)$ \\
\hline 10 & Scandal & \multicolumn{2}{|c|}{ An externally (press) initiated event } & $3(1)$ & $3(1)$ \\
\hline 11 & Not published & \multicolumn{2}{|c|}{ No communication at all } & $18(6)$ & $13(5)$ \\
\hline \multicolumn{6}{|c|}{ Panel 2 Resulting sub-samples and their sizes } \\
\hline \multicolumn{3}{|c|}{ Sub-sample } & \multicolumn{2}{|l|}{ Exit motives* } & Sample size \\
\hline \multicolumn{3}{|c|}{ 1. Total sample } & & & 227 \\
\hline \multicolumn{3}{|c|}{ 2. All unanticipated departures } & \multicolumn{2}{|l|}{ Sample-1,11 (left) } & 123 \\
\hline \multicolumn{3}{|c|}{ 3. Death or health related departures } & \multicolumn{2}{|l|}{2,3} & 15 \\
\hline \multicolumn{3}{|c|}{ 4. Forced departures, published } & \multicolumn{2}{|l|}{$7,8,9,10$ (left) } & 30 \\
\hline \multicolumn{3}{|c|}{ 5. Forced departures, published plus speculated } & \multicolumn{2}{|l|}{$7,8,9,10$ (right) } & 41 \\
\hline \multicolumn{3}{|c|}{ 6. Forced departures, successor not announced } & \multicolumn{2}{|c|}{ Part of $7,8,9,10$ (right) } & 28 \\
\hline \multicolumn{3}{|c|}{ 7. Forced departures, successor announced } & \multicolumn{2}{|c|}{ Part of $7,8,9,10$ (right) } & 13 \\
\hline
\end{tabular}

Note *Numbers correspond to numbers in the first column of Panel 1.

Panel 2 shows the relevant sub-samples for which abnormal price and trading volumes effects will be calculated. We consider the samples of departures due to health and death as a benchmark since these are obviously not due to monitoring in any way. We further analyze the sub-sample of 30 forced departures according to the published exit motive and the larger sub-sample of 41 forced departures, including those that were not officially published as such. ${ }^{18}$

The sub-sample of forced departures is further split according to two characteristics of the event: (i) whether a successor appointment is announced simultaneously, and (ii) the function of the top executive (CEO or not). The first split is relevant for the identification of the contaminating effect of successor appointments, the second for a comparison to the many studies that consider CEO's exclusively.

The abnormal return $\left(A R_{i, t}\right)$ on company stock of share $i$ at day $t$, measuring the stock price effect of the event, is calculated as the realized ex post return $\left(R_{i, t}\right)$ over the event window minus the expected

${ }^{18}$ Table 1 shows that the size of this sub-sample, though not large, is within the usual range. 
return $E\left(R_{i, t}\right)$ as defined by the estimated result without event: $A R_{i, t}=R_{i, t}-E\left(R_{i, t}\right)$. We calculate $E\left(R_{i, t}\right)$ by using two alternative common approaches: the Constant Mean Returns model (CMR), and the OLS Market model (OLM). The CMR model assumes a constant expected return to share i, $K_{i}$, where $K_{i}=$ $\frac{1}{N} \sum_{d=-N}^{-1} R_{i, t}$, and the estimation window is measured over the interval $[-N, \ldots \ldots,-1]$. The OLM model relates the returns of any given security $(i)$ to the returns of the market portfolio $(m)$ at time $t . E\left(R_{i, t}\right)=$ $R_{m, t}$ where $m$ defines the market portfolio considered. ${ }^{19}$ Alpha's and beta's for each security $i$ were obtained by estimating $R_{i t}=\alpha_{i}+\beta_{i} R_{m t}+\varepsilon_{i t}$ by means of OLS with daily returns over a period of 200 to 10 days prior to the announcement day 0 and $\varepsilon_{i t} \sim \mathrm{N}\left(0, \sigma_{\varepsilon t}^{2}\right)$. We obtain the following expressions for abnormal returns:

- CMR-model: $A R_{i, t}=R_{i, t} K_{i}$, where $K_{i}=\frac{1}{N} \sum_{d=-N}^{-1} R_{i, t}$

- OLM-model: $A R_{i, t}=R_{i, t}-\hat{\alpha}_{i}-\hat{\beta}_{i} R_{m t}$

The design of the analysis of abnormal trading volume effects is the same as for abnormal returns. We formulate the Constant Mean Trading (CMT) volume model in analogy to the CMR model: $A V_{i, t}=V_{i, t}-\bar{V}_{i}$, where $V_{i, t}=$ the realized daily trading volume of company $i$ during the event window, $\bar{V}_{i}=$ the average daily trading volume of company $i$ during the estimation window, and $A V i, t=$ the abnormal daily trading volume of company $i$ explained by the event. A rank test can be applied after $A V i, t$ has been calculated for all $i[1, \ldots, \mathrm{N}] .{ }^{20}$ The rank values only enable the calculation of the significance of aggregate abnormal trading volumes, not of their values. Standardized rank values (TS) are calculated for all observations within each estimation window. This allows testing the null hypothesis Ts $=0.5$.

\subsection{Governance related determinants of returns and trading volume effects of forced departures}

Governance-related firm characteristics that potentially influence control and thereby the value effects of forced departures considered for the sample of 41 forced departures are (i) Whether a firm had adopted at the time of the departure (a) the mandatory structuur regime, (b) the voluntary structuur regime, or (c) no structuur regime; (ii) The number of priority shares issued; (iii) Whether the firm had certificated shares, and (iv) The ownership structure of the firm, characterized by the concentration of shareholders, in terms of the percentages held by the one and three largest shareholders. ${ }^{21}$ Note that we

${ }^{19}$ Brown and Warner (1985) conclude that these models are effective ways to determine expected return with daily data. MacKinlay (1997) concludes that multi-factor models do not lead to significantly better results than these one-factor models.

20 The t-test is omitted because the normality assumption of the distribution of daily trading volumes of an individual security is clearly violated: Volumes are non-negative by definition with only a small downside deviation, whereas the upside deviation is possibly infinite.

${ }^{21}$ Only one of these concentration measures is included in the regression equations, due to their high correlation. We also considered whether a major restructuring (M\&A, divestiture, filing for bankruptcy etc.) took place within 
will not estimate the effect of preferred shares, the third commonly used takeover defense, since this defense measure does not change control in any way in the absence of a hostile takeover threat.

Three quarter of the 41 firms had adopted the structuur regime at the time the executive was forced to leave office. For 13 out of these 31 firms this was mandatory. ${ }^{22}$ Moreover, $30 \%$ of the firms had issued one or more priority shares, whereas $40 \%$ traded certificates of shares.

\section{$6 \quad$ Results and discussion}

We first discuss the empirical results pertaining to price effects, both average and individual. This will allow a comparison of our results to previous studies. We will subsequently discuss trading volume effects to get a better and more profound understanding of the value relevance of board monitoring. The final part in this section discusses the event- and governance-related determinants of cross-sectional heterogeneity in abnormal returns and trading volumes resulting from forced departures.

\subsubsection{Average stock return effects}

Table 3 shows that the average abnormal return pertaining to the announcement of an executive's departure is insignificant for most categories of departures in all event windows. In particular, forced executive departures show no significant average price effect in general. This is consistent with the mixed findings of previous studies, in particular with Warner et. al (1988), Dherment-Ferere and Renneboog (2002), and Danisevska et al. (2004) and does not support value relevant board monitoring.

One sub-sample, however, shows a significant average effect in the most relevant event window $d=0$ (and also $d=[0,1]$ ). When a dismissal is announced simultaneously with a successor appointment, a highly significant positive abnormal return of $5 \%$ is observed. This finding is consistent with several previous studies (cf. Warner et al., 1988; Kang and Shivdasani, 1996; Huson et al. 2001; DhermentFerere and Renneboog, 2002) and supports the notion by Furtado and Rozeff (1987) that most effects of dismissals previously found are biased upwards due to the simultaneous announcement of a successor appointment. ${ }^{23}$ The sub-sample of CEO dismissals echoes this effect since CEO departures in particular are announced simultaneously with successor appointments (11 out of 15 cases): It shows a marginally significantly positive price effect of almost $4 \%$ on average.

All average abnormal returns are insignificant during event windows $d=-1$ and in the ten day period previous to announcement, indicating that there is no leakage of top executive dismissal decisions. In addition, extending the $d=0$ window with one extra day, capturing possible lagged effects does not influence the effect, as is expected in an efficient capital market.

3 months prior to the departure. However, this was the case for only two of the 41 forced departures, so we did not pursue including this variable in the regression equations.

${ }^{22}$ Information about legal form was obtained from Deminor (NL) for all relevant firm-year observations.

${ }^{23}$ The result is also consistent with Hayes and Shaefer (1999) who view management hiring and firing as a matching process. A stock price increase upon the simultaneous announcement of a forced departure and a successor indicates that the company has found a new manager whose skills are believed to be a better match for the company. 
Table 3

Average stock price effects

\begin{tabular}{|c|c|c|c|c|c|}
\hline \multicolumn{2}{|l|}{ Panel 1 Event window I: $[d=0]$} & \multicolumn{2}{|c|}{ CMR-model } & \multicolumn{2}{|c|}{ OLM-model } \\
\hline Sample & $\mathrm{N}$ & AR $(\%)$ & t-value & AR $(\%)$ & t-value \\
\hline 1.Total sample & 227 & 0.29 & 1.1 & 0.21 & 0.9 \\
\hline 2. All unanticipated departures & 123 & 0.43 & 1.1 & 0.23 & 0.6 \\
\hline 3. Death or health related departures & 15 & $1.31 *$ & 1.7 & 1.24 & 1.4 \\
\hline 4. Forced departures, published plus speculated & 41 & 1.07 & 1.1 & 0.87 & 1.0 \\
\hline 5. Forced departures, published & 30 & 1.69 & 1.2 & 1.00 & 0.8 \\
\hline 6. Forced departures, successor not announced & 28 & -0.73 & 0.8 & -0.89 & 1.1 \\
\hline 7. Forced departures, successor announced & 13 & $4.93 * *$ & 2.3 & $4.67 * *$ & 2.3 \\
\hline 8. Forced CEO departures & 14 & $3.93 *$ & 1.9 & $3.78^{*}$ & 1.9 \\
\hline \multicolumn{2}{|l|}{ Panel 2 Event window II: $[d=-10, d=-1]$} & \multicolumn{2}{|c|}{ CMR- model } & \multicolumn{2}{|c|}{ OLM-model } \\
\hline Sample & $\mathrm{N}$ & AR (\%) & t-value & AR $(\%)$ & t-value \\
\hline 1.Total sample & 227 & -0.65 & 1.5 & -0.56 & 1.4 \\
\hline 2. All unanticipated departures & 123 & -0.67 & 1.0 & -0.65 & 1.1 \\
\hline 3. Death or health related departures & 15 & $-0.38^{*}$ & 1.7 & -0.25 & 1.2 \\
\hline 4. Forced departures, published plus speculated & 41 & -0.38 & 0.3 & -0.89 & 0.9 \\
\hline 5. Forced departures, published & 30 & -0.92 & 0.6 & -0.89 & 0.8 \\
\hline 6. Forced departures, successor not announced & 28 & -1.02 & 0.9 & -1.27 & 1.4 \\
\hline 7. Forced departures, successor announced & 13 & 1.01 & 0.4 & -0.06 & 0.2 \\
\hline 8. Forced CEO departures & 14 & -0.14 & 0.1 & -0.91 & 0.5 \\
\hline \multicolumn{2}{|l|}{ Panel 3 Event window III: $[d=-1]$} & \multicolumn{2}{|c|}{ CMR- model } & \multicolumn{2}{|c|}{ OLM-model } \\
\hline Sample & $\mathrm{N}$ & AR (\%) & t-value & $\mathrm{AR}(\%)$ & t-value \\
\hline 1.Total sample & 227 & -0.03 & 0.3 & 0.01 & 0.1 \\
\hline 2. All unanticipated departures & 123 & -0.03 & 0.2 & -0.02 & 0.4 \\
\hline 3. Death or health related departures & 15 & -0.55 & 0.9 & -0.12 & 0.3 \\
\hline 4. Forced departures, published plus speculated & 41 & 0.30 & 1.3 & 0.14 & 0.8 \\
\hline 5. Forced departures, published & 30 & 0.53 & 1.5 & 0.35 & 1.2 \\
\hline 6. Forced departures, successor not announced & 28 & 0.58 & 1.6 & 0.13 & 0.5 \\
\hline 7. Forced departures, successor announced & 13 & 0.49 & 1.3 & 0.17 & 0.5 \\
\hline 8. Forced CEO departures & 14 & 0.44 & 1.5 & 0.51 & 1.4 \\
\hline \multicolumn{2}{|l|}{ Panel 4 Event window IV: $[d=0$ to 1$]$} & \multicolumn{2}{|c|}{ CMR-model } & \multicolumn{2}{|c|}{ OLM-model } \\
\hline Sample & $\mathrm{N}$ & AR $(\%)$ & t-value & $\operatorname{AR}(\%)$ & t-value \\
\hline 1.Total sample & 227 & 0.40 & 1.3 & 0.26 & 1.0 \\
\hline 2. All unanticipated departures & 123 & 0.46 & 1.0 & 0.17 & 0.7 \\
\hline 3. Death or health related departures & 15 & 0.20 & 1.0 & 0.14 & 1.0 \\
\hline 4. Forced departures, published plus speculated & 41 & 0.97 & 0.9 & 0.75 & 0.9 \\
\hline 5. Forced departures, published & 30 & 1.40 & 1.0 & 0.66 & 0.6 \\
\hline 6. Forced departures, successor not announced & 28 & -1.06 & 1.1 & -1.31 & 1.5 \\
\hline 7. Forced departures, successor announced & 13 & $5.36 * * *$ & 2.5 & $5.17 * * *$ & 2.5 \\
\hline 8. Forced CEO departures & 14 & $3.93 *$ & 1.8 & $3.89 *$ & 1.9 \\
\hline
\end{tabular}

Note The table shows the abnormal return (AR) within each sub-sample, and absolute t-values. The first set of results has been achieved using the Constant Mean Returns (CMR) model, the second set using the OLS Market (OLM) model. $*=$ significance level of $90 \%$; ** = significance level of $95 \%$; ***= significance level of $99 \%$.

\subsubsection{Individual stock price effects}

Table 4 shows the percentages of events per sub-sample that generate significant abnormal returns, in total, positive and negative. The percentage of significant effects (the percentages in the columns "AR") is significant (compared to the statistically expected 5\%) for both the CMR and the OLM model in all sub-samples in the event windows $d=0$ and $[d=0,1]$, except for the sub-sample of 'death or health 
related departures'. At the day of announcement, 12 to 14 percent of the forced turnover events generate significant positive or negative price effects. The equality of the number of events with significantly positive and negative price effects is consistent with, though not necessary for, the insignificant average price effects.

We classify events with a significant individual price effect of any sign as "dominated events". Approximately a quarter of the forced turnovers belong to the class of dominated events. ${ }^{24}$ Hence, the majority of the dismissals show insignificant price effects. Whether these events are value-relevant and fall in the category of, what we call, "disagreement events" can neither be concluded from the mere analysis of price effects, nor from the analysis of shifts in variances (see Table A.1). Therefore, our next step will be a trading volumes analysis.

\section{Table 4}

Percentage of Events with Individual Abnormal Stock Returns

\begin{tabular}{|c|c|c|c|c|c|c|c|}
\hline \multicolumn{2}{|l|}{ Panel 1 Event window I: $[d=0]$} & \multicolumn{3}{|c|}{ CMR- model } & \multicolumn{3}{|c|}{ OLM-model } \\
\hline Sample & $\mathrm{N}$ & AR & $\mathrm{AR}+$ & AR - & AR & $\mathrm{AR}+$ & AR - \\
\hline 1.Total sample & 227 & $19.0 \% * * *$ & $10.6 \%$ & $8.4 \%$ & $22.0 \% * * *$ & $11.9 \%$ & $10.1 \%$ \\
\hline 2. All unanticipated departures & 123 & $22.0 \% * * *$ & $11.4 \%$ & $10.6 \%$ & $26.8 \% * * *$ & $14.6 \%$ & $12.2 \%$ \\
\hline 3. Death or health related departures & 15 & $13.3 \%$ & $13.3 \%$ & $0.0 \%$ & $20.0 \% * * *$ & $20.0 \%$ & $0.0 \%$ \\
\hline 4. Forced departures, published + speculated & 41 & $24.4 \% * * *$ & $12.2 \%$ & $12.2 \%$ & $24.4 \% * * *$ & $12.2 \%$ & $12.2 \%$ \\
\hline 5. Forced departures, published & 30 & $28.6 \% * * *$ & $14.3 \%$ & $14.3 \%$ & $28.6 \% * * *$ & $14.3 \%$ & $14.3 \%$ \\
\hline 6. Forced departures, successor not announc & 28 & $17.9 \% * * *$ & $3.6 \%$ & $14.3 \%$ & $21.4 \% * * *$ & $7.1 \%$ & $14.3 \%$ \\
\hline 7. Forced departures, successor announced & 13 & $38.5 \% * * *$ & $30.8 \%$ & $7.7 \%$ & $38.5 \% * * *$ & $30.8 \%$ & $7.7 \%$ \\
\hline 8. Forced CEO departures & 14 & $33.4 \% * * *$ & $26.7 \%$ & $6.7 \%$ & $33.4 \% * * *$ & $26.7 \%$ & $6.7 \%$ \\
\hline \multicolumn{2}{|l|}{ Panel 2 Event window II: $[d=-10,-1]$} & \multicolumn{3}{|c|}{ CMR- model } & \multicolumn{3}{|c|}{ OLM-model } \\
\hline Sample & $\mathrm{N}$ & AR & $\mathrm{AR}+$ & AR - & AR & $\mathrm{AR}+$ & AR - \\
\hline 1.Total sample & 227 & $10.5 \% * * *$ & $3.5 \%$ & $7.0 \%$ & $7.0 \%$ & $2.6 \%$ & $4.4 \%$ \\
\hline 2. All unanticip & 123 & $13.8 \% * * *$ & $4.9 \%$ & $8.9 \%$ & $12.2 \% * * *$ & $4.1 \%$ & $8.1 \%$ \\
\hline ed departures & 15 & $20.0 \% * * *$ & $6.7 \%$ & $13.3 \%$ & $13.3 \%$ & $0.0 \%$ & $13.3 \%$ \\
\hline 4. Forced departures, published + spec & 41 & $14.2 \% * *$ & $4.9 \%$ & $7.3 \%$ & $9.7 \%$ & $2.4 \%$ & $7.3 \%$ \\
\hline 5. Forced de & 30 & $3.6 \%$ & $3.6 \%$ & $0.0 \%$ & $3.6 \%$ & $3.6 \%$ & $0.0 \%$ \\
\hline uccessor not ann & 28 & $14.2 \% * *$ & $7.1 \%$ & $7.1 \%$ & $10.7 \%$ & $3.6 \%$ & $7.1 \%$ \\
\hline 7. Forced de & 13 & $7.7 \%$ & $0.0 \%$ & $7.7 \%$ & $7.7 \%$ & $0 \%$ & $7.7 \%$ \\
\hline 8. Forced CEO departures & 14 & $6.7 \%$ & $0.0 \%$ & $6.7 \%$ & $6.7 \%$ & $0.0 \%$ & $6.7 \%$ \\
\hline \multicolumn{2}{|l|}{ Panel 3 Event window III: $[d=-1]$} & \multicolumn{3}{|c|}{ CMR- model } & \multicolumn{3}{|c|}{ OLM-model } \\
\hline Sample & $\mathrm{N}$ & AR & $\mathrm{AR}+$ & AR - & AR & $\mathrm{AR}+$ & AR - \\
\hline 1.Total sam & 227 & $6.2 \%$ & $3.1 \%$ & $3.1 \%$ & $7.0 \%$ & $8 \%$ & $2.2 \%$ \\
\hline 2. All unanticipated & 123 & $5.7 \%$ & $2.4 \%$ & $3.3 \%$ & $7.3 \%$ & $4.9 \%$ & $2.4 \%$ \\
\hline ed departures & 15 & $13.4 \%$ & $6.7 \%$ & $6.7 \%$ & $13.4 \%$ & $6.7 \%$ & $6.7 \%$ \\
\hline published + speculated & 41 & $2.4 \%$ & $2.4 \%$ & $0.0 \%$ & $4.9 \%$ & $4.9 \%$ & $0.0 \%$ \\
\hline 5. Forced departu1 & 30 & $0.0 \%$ & $0.0 \%$ & $0.0 \%$ & $3.6 \%$ & $3.6 \%$ & $0.0 \%$ \\
\hline 6. Forced depar & 28 & $3.6 \%$ & $3.6 \%$ & $0.0 \%$ & $7.7 \%$ & $7.7 \%$ & $0.0 \%$ \\
\hline accessor announced & 13 & $0.0 \%$ & $0.0 \%$ & $0.0 \%$ & $7.7 \%$ & $7.7 \%$ & $0.0 \%$ \\
\hline 8. Forced CEO departures & 14 & $0.0 \%$ & $0.0 \%$ & $0.0 \%$ & $6.7 \%$ & $6.7 \%$ & $0.0 \%$ \\
\hline \multicolumn{2}{|l|}{ Panel 4 Event window IV: $[d=0,1]$} & \multicolumn{3}{|c|}{ CMR- model } & \multicolumn{3}{|c|}{ OLM-model } \\
\hline Sample & $\mathrm{N}$ & AR & $\mathrm{AR}+$ & AR - & $\mathrm{AR}$ & $\mathrm{AR}+$ & AR - \\
\hline 1.Total sample & 227 & $13.2 \% * * *$ & $7.0 \%$ & $6.2 \%$ & $14.1 \% * * *$ & $7.9 \%$ & $6.2 \%$ \\
\hline 2. All unanticipated departures & 123 & $17.9 \% * * *$ & $9.8 \%$ & $8.1 \%$ & $18.7 \% * * *$ & $9.8 \%$ & $8.9 \%$ \\
\hline 3. Death or health related depart & 15 & $6.7 \%$ & $6.7 \%$ & $0.0 \%$ & $6.7 \%$ & $6.7 \%$ & $0.0 \%$ \\
\hline
\end{tabular}

${ }^{24}$ Given a significant percentage of dominated events, Warner et al.'s test statistic is expected to indicate a significant shift in the variances of abnormal returns. This is indeed the case (see Table A.1). 


\begin{tabular}{|l|r|r|r|r|r|r|r|}
\hline 4. Forced departures, published + speculated & 41 & $19.6 \% * * *$ & $9.8 \%$ & $9.8 \%$ & $24.4 \% * * *$ & $12.2 \%$ & $12.2 \%$ \\
\hline 5. Forced departures, published & 30 & $28.6 \% * * *$ & $14.3 \%$ & $14.3 \%$ & $32.2 \% * * *$ & $17.9 \%$ & $14.3 \%$ \\
\hline 6. Forced departures, successor not announced & 28 & $17.9 \% * * *$ & $3.6 \%$ & $14.3 \%$ & $21.5 \% * * *$ & $3.6 \%$ & $17.9 \%$ \\
\hline 7. Forced departures, successor announced & 13 & $23.1 \% * * *$ & $23.1 \%$ & $0.0 \%$ & $38.5 \% * * *$ & $30.8 \%$ & $7.7 \%$ \\
\hline 8. Forced CEO departures & 14 & $26.7 \% * * *$ & $20.0 \%$ & $6.7 \%$ & $33.4 \% * * *$ & $26.7 \%$ & $6.7 \%$ \\
\hline
\end{tabular}

Note The table shows the percentage of abnormal returns (AR) within each sub-sample that are individually significant, significantly positive and negative at the $5 \%$ level. The first set of results has been achieved using the Constant Mean Returns (CMR) model, the second set using the OLS Market model. The stars indicate for each set of results whether the total percentage of events with significant abnormal returns is significantly different from $5 \%$. $*$ significance level of $90 \% ; * *=$ significance level of $95 \% ; * *=$ significance level of $99 \%$.

\subsection{Trading volume effects}

Table 5 shows for each event category how highly the average volume at announcement is ranked in comparison to the daily trading volumes of the same firm within the estimation window (200 trading days). The estimation window is partitioned into sub-periods of equal length, all equal to the length of the event window. In the case of $d=0$ this comes down to a ranking over 200 sub-periods of one day, whereas in the case of $d=-10,-1$ this comes down to 20 intervals of ten days. ${ }^{25}$ The lower the rank, the higher is the trading volume during the event window relative to the intervals preceding the announcement. Trading volumes are defined to be abnormally high whenever the rank, $T s$, is significantly lower than 0.50 .

All sub-samples show significant results at announcement (see Panel $1 d=0$, but also Panel $2 d=0,1$ ). As expected, the sub-sample of events that are unrelated to monitoring, i.e. death and health related turnover, forms the exception: These events do not generate significant abnormal trading volumes. Panels I and II further show that trading volume effects are greater for forced departures $(T s=0.29)$ than for all unanticipated departures taken together $(T s=0.41)$. In the sub-samples for which we found (marginally) significant price effects, these volume effects are even larger: $T_{S}=0.25$ for forced CEO dismissals and $T_{s}=0.19$ for simultaneous announcements of a dismissal and a successor appointment.

A ninth sub-sample is shown in Table 5: events that do not generate any significant individual price effect in the event window studied, i.e. the potential set of disagreement events. This sub-sample also shows significantly higher trading volumes in the event windows $d=0$ and $d=0,1: T s=0.38$ and 0.33 respectively. We can therefore conclude that these events are value relevant indeed and are collectively classified as disagreement events.

In order to definitively conclude that increased trading volumes reflect market reactions to announcements of executive departures, the increased volume should not be related to the dismissed executives themselves selling shares. This is indeed the case: Since the 1990's, insider trading is legally forbidden in the Netherlands, in particular for board members, by the "Act on the Supervision of the Securities Trade" (ASST). A dedicated institution, called the Netherlands Authority for the Financial

${ }^{25}$ Twenty is considered as too few observations for reporting the results for this event window in Table 5. 
Markets (AFM), actively monitors the endorsement of the ASST. In the case of evidence of insider trading, the executive concerned is brought to trial. Therefore, the trading volumes effects are unlikely to be caused by the departing executive selling shares.

We conclude that the lack of significant abnormal average stock prices effects is not caused by a lack of interest from investors in forced executive departures. The abnormally high trading volumes show that investors react strongly, but in different ways given the absence of average price effects. This finding supports the Warner hypothesis: Dismissals generate a positive real monitoring effect and an opposing negative information effect. The reaction of the Dutch stock market to forced executive departures reflects value relevant board monitoring of executives.

Table 5

Aggregate trading volume effects

\begin{tabular}{|c|c|c|c|}
\hline Panel 1 Event window I: $[d=0]$ & $\mathrm{N}$ & Ts & $\mid \mathrm{t}$-value $\mid$ \\
\hline 1.Total sample & 205 & $0.38 * * *$ & 6.1 \\
\hline 2. All unanticipated departures & 109 & $0.41 * * *$ & 3.4 \\
\hline 3. Death or health related departures & 14 & 0.43 & 1.0 \\
\hline 4. Forced departures, published plus speculated & 36 & $0.29 * * *$ & 4.4 \\
\hline 5. Forced departures, published & 25 & $0.28 * *$ & 2.3 \\
\hline 6. Forced departures, successor not announced & 25 & $0.33 * * *$ & 2.8 \\
\hline 7. Forced departures, successor announced & 11 & $0.19 * * *$ & 6.7 \\
\hline 8. Forced CEO departures & 13 & $0.25 * * *$ & 3.5 \\
\hline 9. Forced departures where price effect is insignificant & 26 & $0.39 * *$ & 2.1 \\
\hline Panel 2 Event window I: $[d=-1]$ & $\mathrm{N}$ & Ts & $\mid t$-value $\mid$ \\
\hline 1.Total sample & 205 & 0.48 & 1.2 \\
\hline 2. All unanticipated departures & 109 & 0.51 & 0.2 \\
\hline 3. Death or health related departures & 14 & 0.42 & 1.3 \\
\hline 4. Forced departures, published plus speculated & 36 & 0.49 & 0.2 \\
\hline 5. Forced departures, published & 25 & 0.55 & 0.8 \\
\hline 6. Forced departures, successor not announced & 25 & 0.48 & 0.3 \\
\hline 7. Forced departures, successor announced & 11 & 0.52 & 0.3 \\
\hline 8. Forced CEO departures & 13 & 0.56 & 0.9 \\
\hline 9. Forced departures where price effect is insignificant & 35 & 0.51 & 0.2 \\
\hline Panel 3 Event window IV: $[d=0$ to $d=1]$ & $\mathrm{N}$ & Ts & $\mid t$-value $\mid$ \\
\hline 1.Total sample & 205 & $0.40 * * *$ & 4.6 \\
\hline 2. All unanticipated departures & 109 & $0.42 * * *$ & 2.8 \\
\hline 3. Death or health related departures & 14 & 0.47 & 0.4 \\
\hline 4. Forced departures, published plus speculated & 36 & $0.27 * * *$ & 4.9 \\
\hline 5. Forced departures, published & 25 & $0.26 * * *$ & 4.3 \\
\hline 6. Forced departures, successor not announced & 25 & $0.31 * * *$ & 3.2 \\
\hline 7. Forced departures, successor announced & 11 & $0.18 * * *$ & 4.9 \\
\hline 8. Forced CEO departures & 13 & $0.22 * * *$ & 4.1 \\
\hline 9. Forced departures where price effect is insignificant. & 28 & $0.33 * * *$ & 3.0 \\
\hline
\end{tabular}

Note The table shows the average of the standardized values of abnormal turnover within each sub-sample. The lower Ts-values, below 0.5, the higher the standardized abnormal turnover ranks. The t-test tests whether the standardized rank is significantly different from 0.5. The number of observations per sub-sample is slightly lower than in Table 4 and 5 because, out of the total sample, 22 turnover values are unavailable. Event window d=-10 to $\mathrm{d}=-1$ is omitted because this relatively long window didn't allow an accurate calculation of ranks. $*=$ significance level of $90 \%$; $* *=$ significance level of $95 \%$; ***= significance level of $99 \%$. 


\subsection{Analysis of variance of stock price and trading volume effects}

Do particular event and governance-related firm characteristics influence the stock price and trading volume effects of the announcements of forced departures? The combined results so far already showed tentative evidence of the effects of some event characteristics: Dismissals with simultaneous successor announcements showed the highest percentage of positively significant individual price effects, $30.8 \%$. Conversely, for the sub-sample of forced departures without successor announcements, negative price effects dominate. We evaluate these tentative effects by means of regression analyses. We also include the governance-related firm characteristics from subsection 5.2 into these analyses.

Table 6

Determinants of stock returns (MAR, CMR) and trading volumes (CMT) ( at $d=0$ for the sample of dismissals; OLS-result)s

\begin{tabular}{|l|l|l|l|}
\hline Panel A: event-characteristics & \multicolumn{3}{|c|}{ Coefficient (absolute t-value) } \\
\hline Determinant & OLM $^{(\mathbf{a})}$ & $\mathbf{C M R}^{(\mathbf{b})}$ & CMT $^{(\mathbf{c})}$ \\
\hline Dummy: successor announced simultaneously & $.0526^{* *}(2.04)$ & $.0564^{* *}(2.00)$ & $-.1996(1.46)$ \\
\hline Dummy: CEO dismissal & $.0178(0.70)$ & $.0142(0.52)$ & $.0266(0.20)$ \\
\hline $\begin{array}{l}\text { Dummy: external successor announced } \\
\text { simultaneously }\end{array}$ & $-.0197(0.43)$ & $-.0223(0.44)$ & $.0102(0.13)$ \\
\hline Dummy: exit motive "forced" speculated & $-.0055(0.28)$ & $-.0134(0.63)$ & $-.0037(0.03)$ \\
\hline Constant & $-.0089(0.66)$ & $-.0045(0.31)$ & $.3291^{* * *}(4.49)$ \\
\hline Sample size & 41 & 41 & 36 \\
\hline Adjusted R-squared & 0.14 & 0.12 & 0.01 \\
\hline
\end{tabular}

\begin{tabular}{|l|l|l|l|}
\hline Panel B: governance-characteristics & \multicolumn{3}{|c|}{ Coefficient (absolute t-value) } \\
\hline Determinant & OLM $^{(\mathbf{a})}$ & $\mathbf{C M R}^{(\mathbf{b})}$ & CMT $^{(\mathbf{c})}$ \\
\hline Dummy: Structuur regime & $0.0152(0.54)$ & $0.0160(0.54)$ & $0.2179^{*}(1.90)$ \\
\hline Dummy: Structuur regime mandatory & $-.0195(0.78)$ & $-.0166(0.63)$ & $-.1310(1.17)$ \\
\hline Dummy: Certificates traded & $-.0263(1.22)$ & $-0.0214(0.94)$ & $0.0417(0.42)$ \\
\hline Priority shares issued & $-.0002^{* *}(2.38)$ & $-.0002^{* *}(2.41)$ & $-.0006(1.53)$ \\
\hline $\begin{array}{l}\text { Proportion of shares held by top 3 } \\
\text { shareholders }\end{array}$ & $0.0192(0.45)$ & $0.0190(0.42)$ & $-.5732^{* * *}(2.90)$ \\
\hline Constant & $0.0220(1.02)$ & $0.0184(0.81)$ & $0.2437^{* *}(2.70)$ \\
\hline Sample size (1) $^{\text {Adjusted R-squared }}$ & 36 & 36 & 31 \\
\hline & 0.05 & 0.04 & 0.21 \\
\hline
\end{tabular}

\begin{tabular}{|c|c|c|c|}
\hline Panel C Characteristics combined $^{(2)}$ & \multicolumn{3}{|c|}{ Coefficient (absolute t-value) } \\
\hline Determinant & OLM $^{(\mathbf{a})}$ & $\mathbf{C M R}^{(\mathbf{b})}$ & $\mathbf{C M T}^{(\mathrm{c})}$ \\
\hline Dummy: successor announced simultaneously & $0.0514 * *(2.68)$ & $0.0533 * *(2.58)$ & $-.089(0.90)$ \\
\hline Dummy: Structuur regime & $0.0123(0.57)$ & $0.0181(0.78)$ & $0.159(1.63)$ \\
\hline Priority shares issued & $-.0002 *(1.96)$ & $-.0002 * *(2.18)$ & $-.0006(1.66)$ \\
\hline $\begin{array}{l}\text { Proportion of shares held by top } 3 \\
\text { shareholders }\end{array}$ & $0.0073(0.19)$ & $0.0049(0.12)$ & $-.581 * * *(3.10)$ \\
\hline Constant & $-.0133(0.68)$ & $-.0157(0.74)$ & $.306^{* * *}(3.45)$ \\
\hline Sample size $^{(1)}$ & 39 & 39 & 34 \\
\hline Adjusted R-squared & 0.20 & 0.20 & 0.22 \\
\hline
\end{tabular}

Note (a) OLM=OLS Market model. Coefficients*100 indicate the effect of the regressors on the percentage change of the stock price (relative to what would be expected based on the stock market development) subsequent to the announcement of the executive dismissal. 
(b) $\mathrm{CMR}=\mathrm{Constant}$ Market Returns model. Coefficients*100 indicate the effect of the regressors on the percentage change of the stock price (relative to what would be expected based on the recent history of the specific stock) subsequent to the announcement of the executive dismissal.

(c) $\mathrm{CMT}=$ Constant Market Trading Volumes Model. Coefficients indicate the effect of the regressors on the change in the standardized ranking of the stock volume (relative to the trading volumes in recent history, i.e. last 200 days of the specific stock) subsequent to the announcement of the executive dismissal. A coefficient of 0.01 indicates that a change of 1 unit in the regressor leads to a one percent lower ranking of the trading volume, ceteris paribus.

$*$ significance level of $90 \% ; * *=$ significance level of $95 \%$; ***= significance level of $99 \%$.

${ }^{(1)}$ For 5 out of the 41 firms data about trading volumes are unavailable. For two firms, data about legal structure are unavailable. For three firms it is unknown whether certificates are traded.

${ }^{(2)}$ Significant characteristics in any of the regression equations in Panel A or B are included in Panel C.

Table 6 shows the results from regression analyses of the price and volume effects in event window $d=0$. Panel $A$ includes the event-related characteristics only, whereas Panel $B$ shows the results from analyses that include the governance-related characteristics only. Panel $C$ combines these.

Panel $A$ confirms that the only event-related characteristic that significantly determines the extent of abnormal returns subsequent to the announcement of a forced departure is a simultaneous successor appointment: This increases the abnormal return on average by five percent points. Monitoring by the supervisory board is more value relevant if the announcement of a dismissal is accompanied by a simultaneous successor announcement. Apparently, it signals that the supervisory board is 'in control': The dismissal is no surprise and there is no uncertainty about the person and timing of the succession. Whether the dismissed board member is the CEO or not does not matter. Moreover, the price effects pertaining to external and internal successor announcements are not significantly different from each other. Furthermore, dismissals announced officially generate price effects that are not significantly different from those of departures that are allegedly forced. The third column of Panel A shows that none of the event-related characteristics affect trading volumes significantly.

Panel $B$ shows the effect of governance-related characteristics (measured in the year of the executive dismissal). The effects of the legal form adopted by the firm, i.e. structuur regime or not and, if so, whether that was mandatory or voluntary, are insignificant. Panel B shows furthermore that the effect of the anti-takeover defense mechanism of certificates is insignificant, whereas the issuing of priority shares has a small but significantly negative effect on the abnormal returns subsequent to the dismissal of an executive: This is consistent with less effective control. Finally, Panel B shows that share ownership concentration does not affect abnormal stock returns, but is the only significant determinant of trading volumes: The more concentrated ownership is, the higher the trading volume is. If the ownership of shares by the three most prominent shareholders increases by one percent, the relative ranking of trading volumes increases by 0.58 percent. This suggests that larger shareholders react more actively (but not more uniformly!) to an executive dismissal than smaller shareholders.

Panel $C$ combines Panels $A$ and $B$ and shows the effect of the regressors from the above panels that were (marginally) significant in at least one case. The panel reinforces the separate effects shown in the other panels. 
The theoretical value creating effect of board monitoring in contrast to the inconclusive empirical results is puzzling. We have contributed to the understanding of this puzzle by addressing and testing three possible explanations.

We test the validity of Warner et al.'s (1988) explanation implying that price effects underestimate the value relevance of internal monitoring due to two opposing and value relevant signals. Our results from an analysis of trading volumes changes subsequent to the announcement of an executive's dismissal support the explanation: Insignificant average abnormal returns go along with abnormal trading volumes. Since insider trading by executives is illegitimate in the Netherlands, these high trading volumes indicate that forced management departures are value relevant. However, investors disagree on whether the positive signal of monitoring is most value relevant or, whether the signal of negative information revealed by the dismissal is more value relevant. We conclude that monitoring is more important than the usual price effects do suggest.

Second, we address the Denis and Denis (1995) explanation for the variety of empirical results: So far, measured stock price effects of forced departures are the joint result of the activities of external and internal control markets and it is not yet clear whether the internal control market would function effectively in isolation. We analyze the effect of forced departures in a country, i.e. the Netherlands, where the effect of board monitoring can be measured almost in isolation due to the virtual absence of the external control market and the rather passive role of shareholders in the period studied. Moreover, we evaluate whether cross-sectional variations in abnormal stock returns and trading volumes can be explained by cross-sectional variations in firm-specific governance characteristics. Board monitoring is value relevant but the more the firm is shielded from outside interference by means of takeover defenses or dispersed ownership, the less value relevant control is. Hence, most studies that include the interrelated effects of both internal and external monitoring probably tend to overestimate the effect of board monitoring by attributing the entire effect to it.

A third factor that we analyze that might explain the lack of consistent empirical results is the contaminating effect of successor announcements. Our results show that the simultaneous announcement of a successor appointment indeed generates a significantly positive price effect, in contrast to all other announcements of forced departures. This finding reinforces our conclusion that board monitoring is value relevant.

We conclude that investors value board monitoring: The disciplinary actions taken by Dutch supervisory boards, i.e. the dismissal of badly performing executives, are consistent with shareholder wealth maximization. However, we have not analyzed the timeliness of such disciplinary actions and therefore we cannot judge whether the manager could or should have been dismissed earlier. Consequently, based on our analyses it is not possible to assess the ultimate effectiveness of board monitoring. 


\section{References}

Allen, M., S. Panian and R. Lotz, 1979. Managerial succession and organization performance: A recalcitrant problem revisited, Administrative Science Quarterly 24, 167-180.

Amir, E. and B. Lev, 1996. Value relevance of nonfinancial information: The wireless communication industry, Journal of Accounting and Economics, 22, 3-30.

Beaver, W., 1968. The information content of annual earnings announcements, Journal of Accounting Research (Supplement), 67-92.

Boeker, W., 1992. Power and managerial dismissal: scapegoating at the top, Administrative Science Quarterly 37(3), 400-421.

Brickley, J., C. Smith and J. Zimmerman, 2003 "Managerial economics and organizational architecture", McGraw-Hill, $3^{\text {rd }}$ edition.

Brown, M., 1982. Administrative succession and organizational performance: The succession effect, Administrative Science Quarterly 27(1), 1-16.

Brown, S. and J. Warner, 1985. Using daily stock returns: The case of event studies, Journal of Financial Economics 14, 3-31.

Coughlan, A. and R. Schmidt, 1985. Executive compensation, management turnover, and firm performance: an empirical investigation, Journal of Accounting and Economics 7, 43-66.

Chen, J., H. Hong and J. Stein, 2001. Forecasting crashes: trading volume, past returns, and conditional skewness in stock prices, Journal of Financial Economics 61(3), 345-381.

Dahya, J., J. McConnell and N. Travlos, 2002. The Cadbury committee, corporate performance and top management turnover, The Journal of Finance 57(1), 461-483.

Danisevska, P., A. De Jong and M. Rosella, 2004. Disciplining managers: Evidence from two-tier boards, working paper.

De Jong, A., R. Kabir, T. Marra and A. Röell, 2001. Ownership and control in the Netherlands, in: 'The control of corporate Europe', F. Barca and M. Becht (Eds.), Oxford University Press, pp. 188-206

De Jong, A., G. Mertens and P. Roosenboom, 2004. "Shareholders' voting at annual meetings: evidence from the Netherlands", working paper.

De Jong, A., D. DeJong, G. Mertens and C. Wasley, 2005. The role and self-regulation in corporate governance: evidence and implications from the Netherlands, Journal of Corporate Finance 11, 473-503.

Dedman, E. and S. Lin, 2002. Shareholder wealth effects of CEO departures: evidence from the UK, Journal of Corporate Finance 1, 81-104.

Denis, D. and D. Denis, 1995. Performance changes following top management dismissals, Journal of Finance 50(4), 1029-1057.

Dherment-Ferere, I. and L. Renneboog, 2002. Share price reactions to CEO resignations and large shareholder monitoring in listed French companies, in Convergence and diversity of corporate governance regimes and capital markets (eds McCahery, J. et al.), 297-324, Oxford University Press.

Espahbodi, H., P. Espahbodi, Z. Rezaee and H. Tehranian, 2002. Stock price reaction and value relevance of recognition versus disclosure: the case of stock-based compensation, Journal of Accounting and Economics, 33(3), 343-373.

Fee, C. and C. Hadlock, 2000. Management turnover and product market competition: Empirical evidence from the US newspaper industry, Journal of Business 73(2), 205-243.

Fee, C. and C. Hadlock, 2004. Management turnover across the corporate hierarchy, Journal of Accounting and Economics 37, 3-38.

Franks, J. and C. Mayer, 2001. Ownership and control of German corporations, The Review of Financial Studies 14(4), 943-977. 
Franks, J., C. Mayer and L. Renneboog, 2001. Who disciplines management in poorly performing countries? Journal of Financial Intermediation 10, 209-248.

Furtado, E. and M. Rozeff, 1987. The wealth effects of company initiated management changes, Journal of Financial Economics 18, 147-160.

Hayes, R.M. and S. Schaefer, 1999, How much are differences in managerial ability worth?, Journal of Accounting and Economics 27, 125-148.

Heflin, F. and K. Shaw, 2000. Blockholder ownership and market liquidity, Journal of Financial and Quantitative Analysis 35(4), 621-633.

Harris, M. and A. Raviv, 1993. Differences of opinion make a horse race, Review of Financial Studies 6, 473506.

Holthausen, R. and R. Watts, 2001. The relevance of the value relevance literature for financial accounting standard setting, Journal of Accounting and Economics, 31, 77-104.

Honée, H., L. Timmerman and M. Nethe, 2000. Rapport inzake de toepassing van de structuurregeling: Zeggenschapsverhoudingen in Nederlandse beursvennootschappen", report for the Ministry of Finance.

Hong, H. and J. Stein, 2003. Differences of opinion, short-sales constraints, and market crashes, Review of Financial Studies 16, 487-525.

Huson, M., M. Parrino, and L. Starks, 2001. Internal monitoring mechanisms and CEO turnover: A long-term perspective, The Journal of Finance 56(6), 2265-2297.

Jensen, M. and K. Murphy, 1990. Performance pay and top-management incentives, Journal of Political Economy 98, 225-264

Jenter, D. and F. Kanaan, 2006. CEO turnover and relative performance evaluation. MIT working paper.

Kabir, R., D. Cantrijn and A. Jeunink, 1997. Takeover defenses, ownership structure and stock returns in the Netherlands: an empirical analysis, Strategic Management Journal 18(2), 97-109.

Kallapur, S. and S. Kwan, 2004. The value relevance of brand assets recognized by UK firms, Accounting Review 79(1), 151-172.

Kandel, E. and N. Pearson, 1995. Differential interpretation of public signals and trade in speculative markets, Journal of Political Economy 103(4), 831-872.

Kang, J. and A. Shivdasani, 1996. Does the Japanese governance system enhance shareholder wealth? Evidence from the stock-price effects of top management turnover, Review of Financial Studies 9(4), 10611095.

Kaplan, S., 1994a. Top executive rewards and firm performance: a comparison of Japan and the United States, Journal of Political Economy 102, 510-546.

Kaplan, S., 1994b. Top executives, turnover and firm performance in Germany, Journal of Law, Economics and Organization 10(1), 142-159

Kaplan, S. and B. Minton, 2006, How has CEO turnover changed? Increasingly performance sensitive boards and increasingly uneasy CEO's, working paper

Kim, O. and R. Verrecchia, 1991. Trading volume and price reactions to public announcements, Journal of Accounting Research 29(2), 302-321

Kim, O. and R. Verrecchia, 1994. Market liquidity and volume around earnings announcements, Journal of Accounting and Economics 17(1-2), 41-67.

Köke, J., 2004. The market for corporate control in a bank-based economy: a governance device?, Journal of Corporate Finance 10, 53-80.

Lausten, M., 2002. CEO turnover, firm performance and corporate governance: empirical evidence on Danish firms, International Journal of Industrial Organization 20(3), 391-414

Lazear, E.P., 1986. Raids and offer matching. Research in Labor Economics 8, 141-165

MacKinlay, A., 1997. Event studies in economics and finance. Journal of Economic Literature 35, 13-39. 
Mahajan, A. and S. Lummer, 1993. Shareholder wealth effects of management changes, Journal of Business Finance and Accounting 20(3), 393-410.

Murphy, K. and J. Zimmerman, 1993. Financial performance surrounding CEO turnover, Journal of Accounting and Economics 16(3), 273-315.

Olie, R., U. Glunk and M. Heijltjes, 2004. Continuity and performance at the top: performance effects of the level, extent, type and frequency of top management team changes. working paper

Renneboog, L., 2000. Ownership, managerial control and the governance of companies listed on the Brussels stock exchange, Journal of Banking and Finance 24, 1959-1995.

Shevlin, T., 1996. The value-relevance of non-financial information: a discussion, Journal of Accounting and Economics 22, 31-42.

Shleifer, A. and R. Vishny, 1997. A survey of corporate governance, Journal of Finance 52(2), 737-783.

Skinner, D., 1996. Are disclosures about bank derivatives and employee stock options 'value-relevant'?, Journal of Accounting and Economics, 22, 393-405.

Van Ees, H., T. Postma and E. Sterken, 2003. Board characteristics and corporate performance in the Netherlands, Eastern Economic Journal 29(1), 41-58.

Van Oijen, P., 2000. Essays on corporate governance with empirical analyses for the Netherlands, Tinbergen Institute PhD Thesis, The Netherlands.

Volpin, P., 2002. Governance with poor investor protection: evidence from top executive turnover in Italy, Journal of Financial Economics 64, 61-90.

Warner, J., R. Watts and K. Wruck, 1988. Stock-prices and top management changes, Journal of Financial. Economics 20(1-2), 461-492.

Weisbach, M., 1988. Outside directors and CEO turnover, Journal of Financial Economics 20, 431-460. 


\section{Appendix}

Table A.1

Mean standardized squared abnormal returns (according to the OLM-model)

\begin{tabular}{|c|c|c|c|}
\hline \multicolumn{2}{|l|}{ Panel 1 Event window I: $[d=0]$} & \multicolumn{2}{|c|}{ OLM-model } \\
\hline Sample & $\mathrm{N}$ & Estimate & $\mid t$-value $\mid$ \\
\hline 1.Total sample & 227 & $2.34 * * *$ & 4.87 \\
\hline 2. All unanticipated departures & 123 & $2.30 * * *$ & 3.72 \\
\hline 3. Death or health related departures & 15 & $1.15^{* * *}$ & 1.35 \\
\hline 4. Forced departures, published + speculated & 41 & $5.10 * * *$ & 2.40 \\
\hline 5. Forced departures, published & 30 & $4.09 * * *$ & 2.54 \\
\hline 6. Forced departures, successor not announced & 28 & $2.20 * * *$ & 2.16 \\
\hline 7. Forced departures, successor announced & 13 & $10.32 * * *$ & 2.25 \\
\hline 8. Forced CEO departures & 14 & $9.37 * * *$ & 2.18 \\
\hline \multicolumn{4}{|l|}{ Panel 2 Event window IV: $[d=0,1]$} \\
\hline Sample & $\mathrm{N}$ & Estimate & $\mid t$-value $\mid$ \\
\hline 1.Total sample & 227 & $1.41 * * *$ & 3.83 \\
\hline 2. All unanticipated departures & 123 & $1.54 * * *$ & 3.25 \\
\hline 3. Death or health related departures & 15 & $1.21 * * *$ & 0.84 \\
\hline 4. Forced departures, published + speculated & 41 & $3.04 * * *$ & 2.13 \\
\hline 5. Forced departures, published & 30 & $2.24 * * *$ & 2.11 \\
\hline 6. Forced departures, successor not announced & 28 & $1.94 * * *$ & 2.10 \\
\hline 7. Forced departures, successor announced & 13 & $5.06 * * *$ & 1.61 \\
\hline 8. Forced CEO departures & 14 & $4.76^{* * *}$ & 1.62 \\
\hline
\end{tabular}

Note The table shows the mean standardized squared abnormal returns according to the formulas in the appendix of Warner et al. (1988). The event windows II $[d=-10,-1]$ and III $[d=-1]$ have been omitted from this table since Table 4 showed few significant numbers for these windows. Hence, panel 2 is comparable to panel 4 in the other tables. The stars indicate for each set of results whether they are significantly different from 1 , the expected value of the distribution of mean standardized squared abnormal returns. $*=$ significance level of $90 \%$; $* *=$ significance level of $95 \%$; $* * *=$ significance level of $99 \%$. The test statistic applied here is only valid in the case of zero average price effects. Therefore, the result of this test demonstrated in the last two sub-samples should be interpreted with great caution since they apply to sub-samples for which the price effects are significant. 